Article

\title{
Combustion Synthesis during Flame Spraying ("CAFSY") for the Production of Catalysts on Substrates
}

\author{
Galina Xanthopoulou *, Amalia Marinou, Konstantinos Karanasios and George Vekinis \\ Institute of Nanoscience and Nanotechnology, National Center for Scientific Research"Demokritos", \\ Aghia Paraskevi, Athens15310, Greece; a.marinou@inn.demokritos.gr (A.M.); konkaranasios@yahoo.gr (K.K.); \\ g.vekinis@inn.demokritos.gr (G.V.) \\ * Correspondence: g.xanthopoulou@inn.demokritos.gr; Tel.: +30-210-650-3348
}

Academic Editor: Eric Loth

Received: 7 November 2016; Accepted: 13 January 2017; Published: 20 January 2017

\begin{abstract}
Combustion-assisted flame spraying ("CAFSY") has been used to produce catalytically active nickel aluminide coatings on ceramic substrates. Their catalytic activity was studied in $\mathrm{CO}_{2}$ (dry) reforming of methane, which is particularly significant for environmental protection as well as production of synthesis gas $\left(\mathrm{CO}+\mathrm{H}_{2}\right)$. By varying the CAFSY processing parameters, it is possible to obtain a range of $\mathrm{Ni}-\mathrm{Al}$ alloys with various ratios of catalytically active phases on the substrate. The influence of the number of coating layers and the type of substrate on the final catalyst composition and on the catalytic activity of the CAFSY coatings was studied and is presented here. The morphology and microstructure of the composite coatings were determined by scanning electron microscopy (SEM) with energy-dispersive X-ray spectroscopy (EDX) elemental analysis, X-ray diffraction (XRD), and Brunauer-Emmett-Teller (BET) specific area analysis. Catalytic tests for dry reforming of methane were carried out using crushed pellets from the coatings at temperatures of $750-900{ }^{\circ} \mathrm{C}$, and gas chromatography showed that methane conversion approached $88 \%$ whereas that of carbon dioxide reached $100 \%$. The $\mathrm{H}_{2} / \mathrm{CO}$ ratio in the synthesis gas produced by the reaction varied from about 0.7 to over 1.2, depending on the catalyst and substrate type and testing temperature.
\end{abstract}

Keywords: thermal spray coating; SHS; catalysts on substrates; dry reforming of methane; syngas

\section{Introduction}

Combustion-assisted flame spraying ("CAFSY") combines conventional flame spraying and powder combustion synthesis into a single step [1,2]. Parameters including the temperature of the flame, the temperature of the substrate, the powder ratio and any pre-treatment of the metal powders, the gas speed and feed rate, and size and condition of starting powders can all be optimized for any particular coating needed. This new method offers a number of advantages over spraying of ready alloyed powders to produce protective coatings on substrates, the main ones being cost and versatility.

$\mathrm{Ni}-\mathrm{Al}$ alloys, made by slow diffusion or by SHS (self-propagating high-temperature synthesis), have been found to display good catalytic properties for a number of chemical reactions. There are many reports on the use of bulk SHS catalysts' activity in different processes [3-12]. Because of the high synthesis temperatures and fast cooling rates achieved, combustion synthesis (CS) and especially SHS produce materials that are characterised by heavily distorted atomic structures, with a very large proportion of catalytically active centres. Many CS catalysts display very enhanced activity compared to the same materials produced by other means, even if they have much lower specific surface area [13]. In this work, we report on the use of the CAFSY method for the production of catalytically active $\mathrm{Ni}-\mathrm{Al}$ alloys sprayed on various substrates for dry $\left(\mathrm{CO}_{2}\right)$ reforming of methane. This process is 
environmentally important, because the mitigation and utilization of greenhouse gases, $\mathrm{CO}_{2}$ and $\mathrm{CH}_{4}$, are among the most significant global challenges. Dry reforming of methane has therefore received much attention from both an environmental and an industrial perspective, as the reaction can convert these greenhouse gases into industrially valuable synthesis gas with a wide range of $\mathrm{H}_{2} / \mathrm{CO}$ ratios.

In a recent report [2], SHS catalysts based on Co-Al-O were shown to exhibit very high catalytic activity for dry reforming of methane with minimal coke production. At a temperature of $900{ }^{\circ} \mathrm{C}$ and atmospheric pressure, $\mathrm{CH}_{4}$ conversion was $100 \%, \mathrm{CO}_{2}$ conversion was about $83 \%$, and the $\mathrm{H}_{2} / \mathrm{CO}$ ratio in the product was about 1.2. Furthermore, at $800{ }^{\circ} \mathrm{C}$, the $\mathrm{CH}_{4}$ conversion was also $100 \%$ but the $\mathrm{H}_{2} / \mathrm{CO}$ ratio reached close to 2 . Such highly promising results, in conjunction with extremely low coke deposition and a high performance maintained over many hours [14], indicates that the SHS method offers significant benefits.

During the past decades, Ni-based catalysts for dry reforming of methane have been extensively studied [15-23]. Previously, we reported [24] that Ni-based catalysts exhibit very high catalytic activity for dry reforming of methane with minimal coke production.

\section{The CAFSY Method for Spraying Catalytically Active Coatings}

Reactive processing of intermetallic materials has been reported in the past [25]. Reaction synthesis (RS) and SHS have been applied for low-energy formation of various binary alloys using a variety of configurations [26-28]. In these studies, the exothermic chemical energy from the reaction between elemental powders is used to synthesise the alloys, thereby reducing the amount of external heating required. CAFSY is attractive for production catalysts because (1) it is a simple operation (requiring minimal operator training and can be used with hand-held sprayers); (2) it gives high spray rates and deposit efficiencies; (3) it works also with low-cost base metal powders of sizes ranging from 5 to $300 \mu \mathrm{m}$; (4) it is possible to change, at any time, the composition of the initial charge, and by adjusting the flame spray conditions, different properties of the coating can be achieved; and, finally; (5) different intermetallic phases can be deposited in one step.

Our previous work $[1,2]$ showed that the $\mathrm{Ni}-\mathrm{Al}$ composite coatings applied by CAFSY were principally composed of three different intermetallic phases (i.e., $\mathrm{NiAl}, \mathrm{Ni}_{2} \mathrm{Al}_{3}, \mathrm{NiAl}_{3}$ ) with small splats of $\mathrm{Al}_{2} \mathrm{O}_{3}$ and $\mathrm{NiAl}_{2} \mathrm{O}_{4}$ phases as well as traces of unreacted nickel and aluminium. In a recent paper [29], we confirmed the catalytic properties of those CAFSY coatings, and the objective of the present paper is to elaborate further on the catalytic properties of $\mathrm{Ni}-\mathrm{Al}$ coated by CAFSY on spinel and refractory substrates for dry reforming of methane.

\section{Materials and Methods}

\subsection{Materials}

The Ni and Al powders were obtained from Sulzer Metco 56C-NS (spheroidal/precipitated powder, particle size 45-75 $\mu \mathrm{m}$ ), and Aluminium Powder Company Ltd (gas fragmentation, 100/D-10, particle size 45-90 $\mu \mathrm{m}$ ), respectively. Substrates used for CAFSY were made of highly macroporous $\mathrm{MgAl}_{2} \mathrm{O}_{4}$ spinel (with some $\mathrm{MgO}$, coded Sp-NiXX-Y, where $\mathrm{XX}$ is the amount of nickel in the initial powder mixture and $\mathrm{Y}$ is the number of gun passes, i.e., coating layers) prepared by SHS from an initial mixture of $\mathrm{Al}+\mathrm{Mg}+\mathrm{Mg}\left(\mathrm{NO}_{3}\right)_{2}+\mathrm{Al}_{2} \mathrm{O}_{3}$. Square plates of dimensions $5 \mathrm{~cm} \times 5 \mathrm{~cm} \times 0.8 \mathrm{~cm}$ were produced using uniaxial compaction under a pressure of $10 \mathrm{MPa}$ and SHS-fired at a preheating temperature of $900^{\circ} \mathrm{C}$ in air. For comparison, substrates made from a porous $\mathrm{Si}-\mathrm{Al}-\mathrm{O}$ refractory brick (BNZ Materials Inc., Littleton, CO, USA, coded RB-NiXX-Y, dimensions $5 \mathrm{~cm} \times 5 \mathrm{~cm} \times 0.8 \mathrm{~cm}$ ) and from a woven glass-fibre refractory mat (BNZ Materials Inc., Littleton, CO, USA, coded RM-NiXX-Y, dimensions $5 \mathrm{~cm} \times 5 \mathrm{~cm} \times 0.3 \mathrm{~cm}$ ) were also used. The porosity of all the above substrates was about $50 \%-70 \%$, which enabled crushing (after coating) to small pieces, which were used for the catalytic tests. 


\subsection{CAFSY Process}

As discussed previously [2,30], CAFSY is based on the exothermic reactions between powders during thermal spraying, as shown schematically in Figure 1. The CAFSY parameters used in this work were described previously [2] and are as follows: ratio of oxygen to acetylene $=1.56$ (acetylene pressure: $32 \mathrm{psi}$, oxygen: $50 \mathrm{psi}$ ), mechanical ball milling of initial mixture ( $\mathrm{Ni}+\mathrm{Al})$ for $10 \mathrm{~min}$, thermal spray distance of $4 \mathrm{~cm}$, substrate temperature of $600{ }^{\circ} \mathrm{C}$, and powder feeding rate of $25 \mathrm{~g} / \mathrm{min}$.

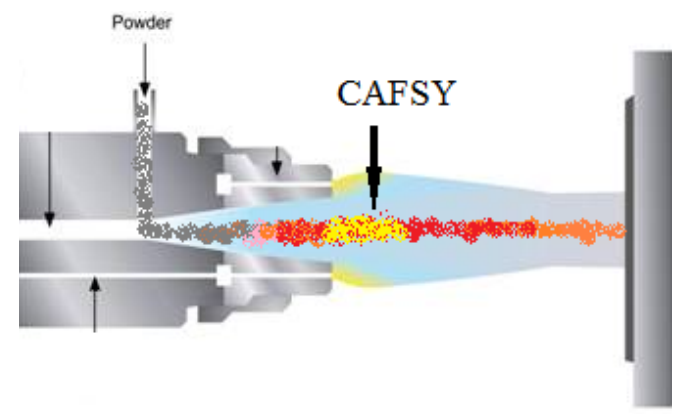

Figure 1. Scheme of combustion-assisted flame spraying (CAFSY) process.

Flame spraying was carried out by a Sulzer's Metco Thermospray Gun (5P-II) (Oerlikon Metco, Winterthur, Switzerland). During spraying, the $\mathrm{Ni}+\mathrm{Al}$ powder mixtures are ignited by the combustion flame and react to produce nickel aluminide compounds, initially in the flame, which are then deposited on the surface and inside the pores of the substrate where the reactions are completed when the substrate temperature is suitable. The CAFSY process has been reported in detail previously [30], where it was shown conclusively that combustion synthesis occurs both in-flight as well as on the substrate. To help with the initiation of the combustion reactions in the flame, the $\mathrm{Ni}$ and $\mathrm{Al}$ particles are partially agglomerated after $10 \mathrm{~min}$ of mechanical treatment. The number of gun passes over the substrate corresponds to the number of coating layers produced on the substrate, which was also found to correlate with the concentration of the catalytic phases in the coatings on the substrate (Table 1). In this work, the following amounts of nickel were used in the $\mathrm{Ni}+\mathrm{Al}$ mixtures: $42.1 \%, 59.3 \%$, $65.1 \%$, and $86.8 \%$ by weight, the remainder being aluminium (Table 1 ). The influence of the number of coating layers on the catalyst composition and the influence of the type of substrate on the catalytic activity of the CAFSY coatings are represented below.

Table 1. Various CAFSY tests and corresponding concentration of catalyst on various substrates.

\begin{tabular}{cccc}
\hline Specimen & Ni in Powder Mixture, wt.\% & $\begin{array}{c}\text { Number of Layers } \\
\text { (Gun Passes) }\end{array}$ & $\begin{array}{c}\text { Concentration of Catalyst } \\
\text { on the Substrate *\% }\end{array}$ \\
\hline Sp-Ni65-2 & 65.1 & 2 & 4.70 \\
Sp-Ni42-2 & 42.1 & 2 & 8.60 \\
Sp-Ni59-2 & 59.3 & 2 & 8.50 \\
Sp-Ni65-1 & 65.1 & 1 & 4.00 \\
Sp-Ni87-2 & 86.8 & 2 & 13.00 \\
Sp-Ni65-5 & 65.1 & 5 & 32.90 \\
Sp-Ni65-8 & 65.1 & 8 & 70.60 \\
Sp-Ni65-2 & 65.1 & 2 & 13.90 \\
RB-Ni65-1 & 65.1 & 1 & 4.00 \\
RM-Ni65-1 & 65.1 & 1 & 4.00 \\
\hline
\end{tabular}

* Concentration of catalysts was determined by measuring the weight of the substrates before and after spraying, which gives the weight of the coating applied.

\subsection{Catalyst Characterisation}

The morphology and microstructure of the composite coatings obtained were examined by scanning electron spectroscopy (SEM) with energy-dispersive X-ray spectroscopy (EDX) elemental 
analysis and X-ray diffraction (XRD). The development of the various intermetallic phases was monitored by calculating the peak ratio of intensities of particular XRD peaks. The peaks we used were as follows. For aluminium metal, $h k l: 111$; for $\mathrm{NiAl}, h k l: 220$; for $\mathrm{Ni}_{3} \mathrm{Al}, h k l: 311$; for $\mathrm{NiAl}_{3}, h k l: 112$; $\mathrm{Ni}_{2} \mathrm{Al}_{3}, h k l: 110$. The peaks used were selected so that they were not clashing with any other peaks in the XRD spectra.

\subsection{Conditions for Catalytic Dry Reforming of Methane}

The catalytic activity of the synthesised catalysts was determined for dry $\left(\mathrm{CO}_{2}\right)$ reforming of methane using coarsely crushed coated substrates with an average pellet size of $3 \mathrm{~mm}$, guided by usual characteristics for industrial catalysts. The tests were carried out in a fixed-bed free-flow quartz reactor without any pre-reduction. All of the tests were conducted at atmospheric pressure in a flow of a gas, which was a mixture of $\mathrm{CO}_{2}-\mathrm{CH}_{4}-\mathrm{N}_{2}$ (ratio 1:1:1), at a flow rate of $30 \mathrm{~mL} / \mathrm{min}$. The total flow rate of reactants was set at $860 \mathrm{~h}^{-1}$ and the catalytic reaction was carried out at 750, 800, 850, and $900{ }^{\circ} \mathrm{C}$. The products were analysed in a gas chromatograph using a $10 \mathrm{~m}$ steel column filled with polymer Highset-d. The outlet gases $\left(\mathrm{O}_{2}, \mathrm{~N}_{2}, \mathrm{CO}, \mathrm{CO}_{2}, \mathrm{CH}_{4}\right)$ were separated at $40^{\circ} \mathrm{C}$ by using a thermal conductivity detector and $\mathrm{He}$ as carrier gas.

\section{Results andDiscussion}

\subsection{Catalyst Characterisation}

The phase composition of the coated catalysts produced by CAFSY on $\mathrm{MgAl}_{2} \mathrm{O}_{4}$ substrates was determined by XRD analysis, and the results are shown in Figure 2 and Table 2.

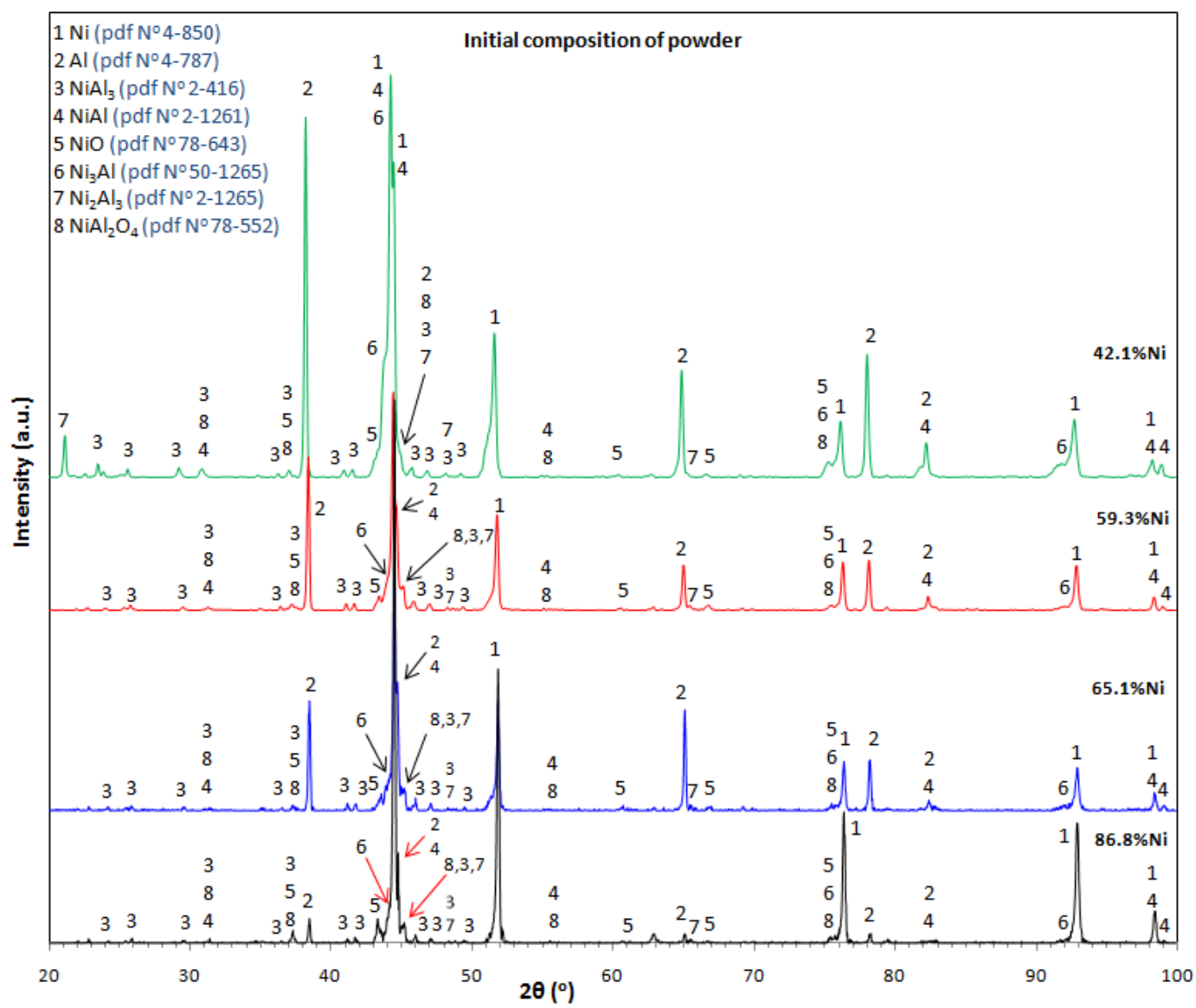

Figure 2. X-ray diffraction (XRD) of CAFSY coatings for different $\mathrm{Ni}+\mathrm{Al}$ starting mixtures after two gun passes. 
Table 2. Initial powder mixture composition and the main catalytically active alloys in the coatings produced by CAFSY on various substrates using only 2 gun passes.

\begin{tabular}{ccc}
\hline Specimen & Initial Mixture Composition & Catalyst Composition \\
\hline Sp-Ni42-2 & $42.1 \% \mathrm{Ni}+57.9 \% \mathrm{Al}$ & $\mathrm{Ni}_{2} \mathrm{Al}_{3}, \mathrm{NiAl}, \mathrm{NiAl}_{3}$ \\
Sp-Ni59-2 & $59.3 \% \mathrm{Ni}+40.7 \% \mathrm{Al}$ & $\mathrm{Ni}_{2} \mathrm{Al}_{3}, \mathrm{NiAl}$ \\
Sp-Ni65-2 & $65.1 \% \mathrm{Ni}+34.9 \% \mathrm{Al}$ & $\mathrm{NiAl}_{2} \mathrm{Ni}_{2} \mathrm{Al}_{3}$ \\
Sp-Ni87-2 & $86.8 \% \mathrm{Ni}+13.2 \% \mathrm{Al}$ & $\mathrm{Ni}_{2} \mathrm{Al}_{3}, \mathrm{NiAl}_{2}, \mathrm{Ni}_{3} \mathrm{Al}$ \\
RB-Ni65-2 & $65.1 \% \mathrm{Ni}+34.9 \% \mathrm{Al}$ & $\mathrm{NiAl}_{1} \mathrm{Ni}_{2} \mathrm{Al}_{3}, \mathrm{NiAl}_{3}, \mathrm{Ni}_{3} \mathrm{Al}$ \\
RM-Ni65-2 & $65.1 \% \mathrm{Ni}+34.9 \% \mathrm{Al}$ & $\mathrm{NiAl}_{2} \mathrm{Ni}_{2} \mathrm{Al}_{3}, \mathrm{NiAl}_{3}, \mathrm{Ni}_{3} \mathrm{Al}$ \\
\hline
\end{tabular}

In all samples, some unreacted $\mathrm{Ni}$ and $\mathrm{Al}$ (except $\mathrm{Sp}-\mathrm{Ni}$ 87-2) are present. This is due to the very limited contact time between particles of $\mathrm{Al}$ and $\mathrm{Ni}$ during flame spraying (of the order of a few milliseconds). Traces of $\mathrm{NiO}$ in all catalysts can be explained by partial oxidation of Ni. There are also traces of $\mathrm{NiAl}_{2} \mathrm{O}_{4}$ in all samples. Main products of nickel aluminides correspond to all stoichiometric compositions of $\mathrm{Ni}: 42.1 \mathrm{wt} . \%\left(\mathrm{NiAl}_{3}\right), 59.3 \mathrm{wt} . \%\left(\mathrm{Ni}_{2} \mathrm{Al}_{3}\right), 65.1 \mathrm{wt} . \%(\mathrm{NiAl})$, and $86.8 \mathrm{wt} . \%\left(\mathrm{Ni}_{3} \mathrm{Al}\right)$. Also, in the case of $42.1 \% \mathrm{Ni}$ in the starting powder mixture, an increased presence of $\mathrm{Ni}_{2} \mathrm{Al}_{3}$ in the coating was observed. At $\mathrm{Sp}-\mathrm{Ni} 87-2$, the presence of $\mathrm{Ni}_{2} \mathrm{Al}_{3}, \mathrm{NiAl}$, and $\mathrm{Ni}_{3} \mathrm{Al}$ in products denotes the enrichment of the NiAl phase with $\mathrm{Ni}$ up to $\mathrm{Ni}_{3} \mathrm{Al}$. In the case of Sp-Ni65-2, only the NiAl phase is evident. This result supports the premise that $\mathrm{NiAl}_{3}, \mathrm{Ni}_{2} \mathrm{Al}_{3}$, and $\mathrm{Ni}_{3} \mathrm{Al}$ formed from enrichment of the $\mathrm{NiAl}$ phase. Figure 2 shows that the maximum content of $\mathrm{NiAl}$ and $\mathrm{Ni}_{2} \mathrm{Al}_{3}$ phases corresponds to their stoichiometric ratio, respectively (the development of the various phases calculated the peak ratio of intensities of the particular XRD peaks: $\left.\mathrm{NiAl}, h k l: 220, \mathrm{Ni}_{2} \mathrm{Al}_{3}, h k l: 110\right)$.

Figure 3 shows the influence of $\mathrm{Ni}$ concentration in the powder mixture on the parameters of the crystal lattice of $\mathrm{NiAl}$ and $\mathrm{Ni}_{2} \mathrm{Al}_{3}$. The increase of $\mathrm{Ni}$ in the powder spraying mixture enriches constantly the $\mathrm{NiAl}$ and $\mathrm{Ni}_{2} \mathrm{Al}_{3}$ phases (up to $65.1 \% \mathrm{Ni}$ for $\mathrm{NiAl}$ and $59.3 \% \mathrm{Ni}$ for $\mathrm{Ni}_{2} \mathrm{Al}_{3}$ phase). Increasing the amount of $\mathrm{Ni}$ (Figure $3 \mathrm{~b}$ ) increases also the size of the crystal lattice spacing from 3.46 to $3.49 \AA$ and from 3.44 to $3.53 \AA$ for NiAl and $\mathrm{Ni}_{2} \mathrm{Al}_{3}$ phases, respectively. This probably occurs because the $\mathrm{Ni}^{2+}$ ionic radius is $0.69 \AA$ and that of $\mathrm{Al}^{3+}$ is $0.51 \AA$.

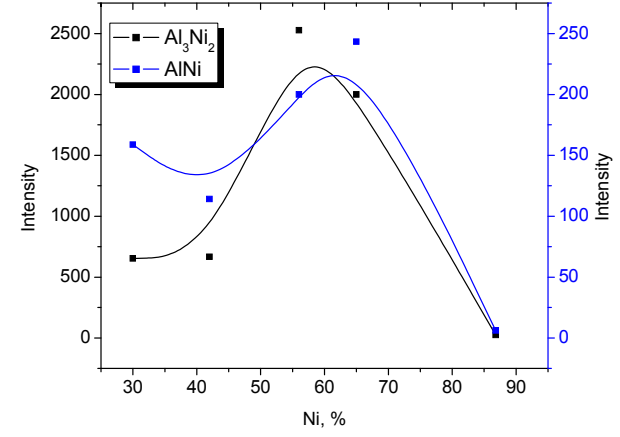

(a)

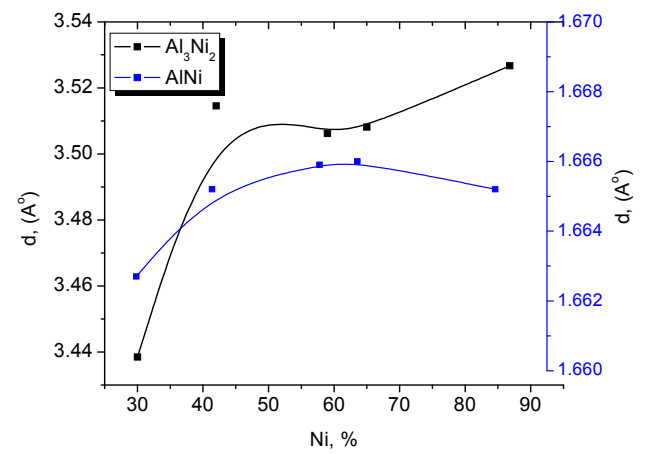

(b)

Figure 3. Influence of $\mathrm{Ni}$ concentration in the powder mixture (coating after two gun passes) on the yield of $\mathrm{NiAl}$ and $\mathrm{Ni}_{2} \mathrm{Al}_{3}(\mathbf{a})$ and on their crystal lattice parameters (b).

The formation of catalytically active coatings (Figure 2 and Table 2) can be explained by combustion synthesis reactions during CAFSY by the following reactions [31]:

$$
\begin{aligned}
\mathrm{Al}+\mathrm{Ni} & \rightarrow \mathrm{NiAl} \\
3 \mathrm{Al}+\mathrm{Ni} & \rightarrow \mathrm{NiAl}_{3} \\
\mathrm{Al}+3 \mathrm{Ni} & \rightarrow \mathrm{Ni}_{3} \mathrm{Al} \\
2 \mathrm{Ni}+3 \mathrm{Al} & \rightarrow \mathrm{Ni}_{2} \mathrm{Al}_{3} \\
2 \mathrm{Ni}+\mathrm{O}_{2} & \rightarrow 2 \mathrm{NiO}
\end{aligned}
$$




$$
\begin{aligned}
4 \mathrm{Al}+3 \mathrm{O}_{2} & \rightarrow 2 \mathrm{Al}_{2} \mathrm{O}_{3} \\
\mathrm{Al}_{2} \mathrm{O}_{3}+\mathrm{NiO} & \rightarrow \mathrm{NiAl}_{2} \mathrm{O}_{4} \\
\mathrm{NiAl}+n \mathrm{Ni} & \rightarrow \mathrm{Ni}_{x} \mathrm{Al}_{y}
\end{aligned}
$$

Nickel aluminides can be formed by the reaction of base metal powders $(\mathrm{Ni}+\mathrm{Al})$ followed by enrichment of the $\mathrm{NiAl}$ phase either during the flight or at the substrate: $\mathrm{NiAl}+n \mathrm{Ni} \rightarrow \mathrm{Ni}_{x} \mathrm{Al}$. As the aluminium melts in the flame (melting point $660^{\circ} \mathrm{C}$ ) it reacts with the heated nickel (melting point $1440{ }^{\circ} \mathrm{C}$ ) and $\mathrm{NiAl}$ (melting point $1911^{\circ} \mathrm{C}$ ) forms exothermically. The heated aluminium and nickel further reacts with $\mathrm{NiAl}$, forming $\mathrm{NiAl}_{3}$ and $\mathrm{Ni}_{3} \mathrm{Al}$, respectively. The simultaneous presence of oxides $\mathrm{NiO}$ and $\mathrm{Al}_{2} \mathrm{O}_{3}$, which form by partial oxidation of the base metals in the combustion flame, are also able to react, forming $\mathrm{NiAl}_{2} \mathrm{O}_{4}$.

The specific surface area of such catalysts is low-about $0.1-0.35 \mathrm{~m}^{2} / \mathrm{g}$ (measured by the BET method (Gold APP Instrument Corporation, Beijing, China) on the coatings)-since the spinel substrates used were also made by SHS, which also have low specific surface area due to the large pores present in such substrates, caused by the melting of the coatings during spraying as evidenced by SEM examinations. A coating made by CAFSY from a powder mixture of $59.3 \% \mathrm{Ni}+40.7 \% \mathrm{Al}$ on $\mathrm{MgAl}_{2} \mathrm{O}_{4}$ spinel studied by SEM/EDS is shown in Figure 4. The EDX spectra are in agreement with the XRD results shown in Figure 2.
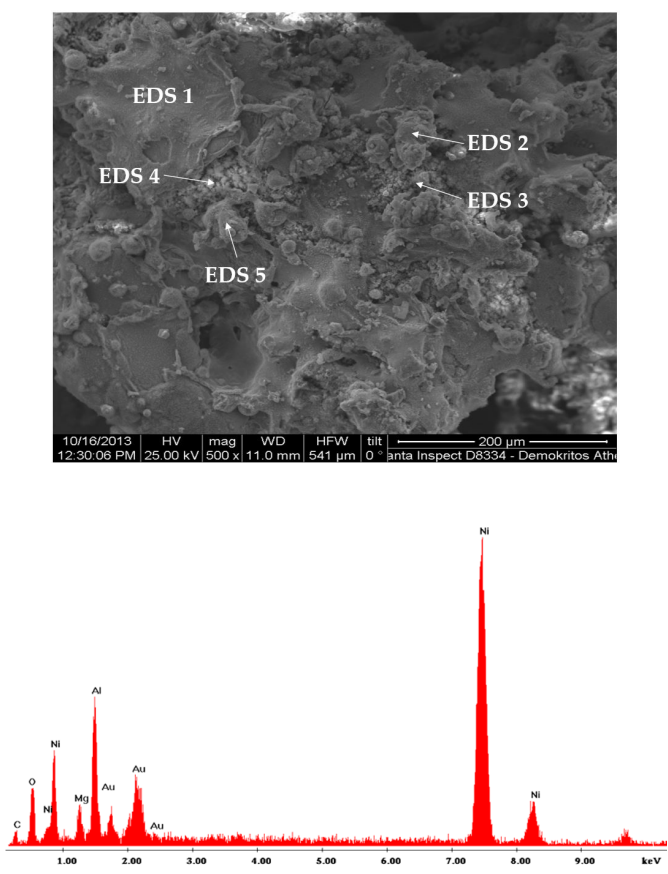

(b) $\mathrm{EDS} 2, \mathrm{Ni}_{2} \mathrm{Al}_{3}$

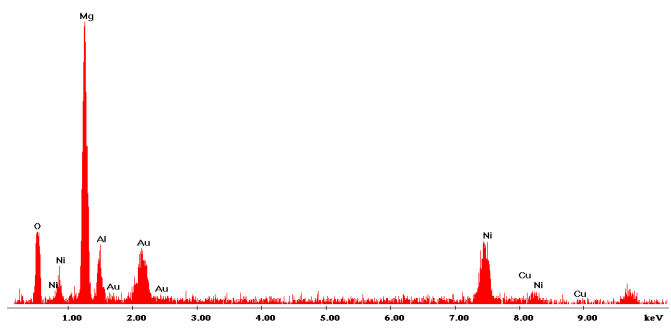

(d) EDS 4, Mg-Al-O spinel

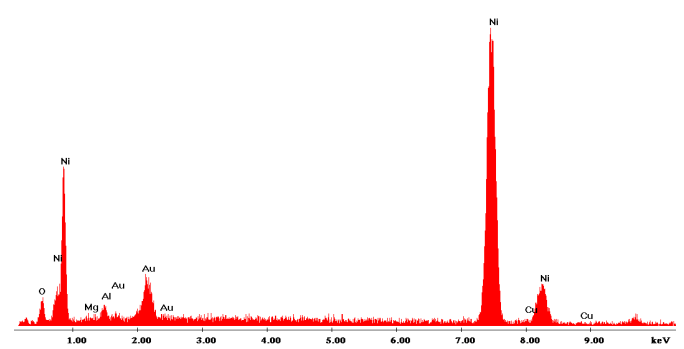

(a) EDS1, Ni

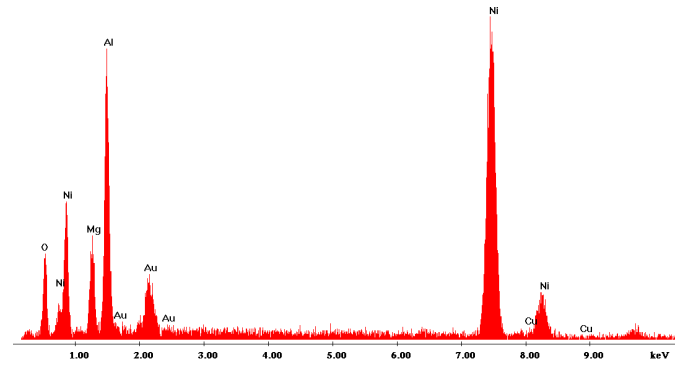

(c) EDS3, NiAl

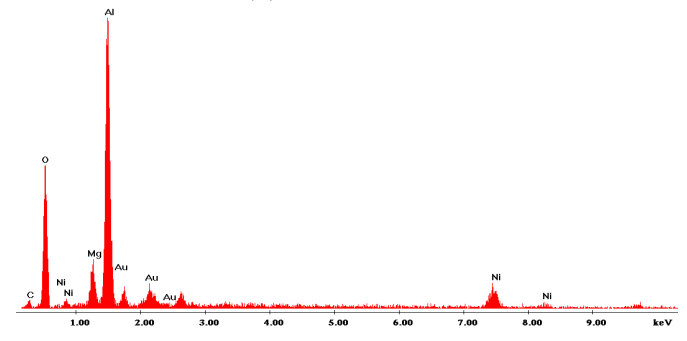

(e) EDS5, $\mathrm{Al}_{2} \mathrm{O}_{3}$

Figure 4. Scanning electron microscopy (SEM)/energy-dispersive X-ray spectroscopy (EDX) analysis of catalytically active coatings Sp-Ni65-2 (initial powder mixture of $65.1 \% \mathrm{Ni}+34.9 \% \mathrm{Al}$ with two gun passes on $\mathrm{MgAl}_{2} \mathrm{O}_{4}$ substrate. The catalytic coating contains about $13.9 \%$ nickel aluminide). (a) EDS 1; (b) EDS 2; (c) EDS 3; (d) EDS 4; (e) EDS 5. 
Increasing the number of gun passes (i.e., layers formed) during thermal spraying (compare SEM photo in Figure 4 (two passes) with SEM photo in Figure 5a (eight passes) increases the coating thickness by approximately $40 \mu \mathrm{m} /$ pass and also heats up the coating, giving additional time to complete the reactions between $\mathrm{NiAl}$ alloys and $\mathrm{Al}$, which gives rise to the $\mathrm{NiAl}_{3}$ phase. A large number of gun passes also results in increased oxidation of nickel and aluminium, producing $\mathrm{NiO}$ and $\mathrm{Al}_{2} \mathrm{O}_{3}$, which react together to form spinel via the reaction $\mathrm{NiO}+\mathrm{Al}_{2} \mathrm{O}_{3} \rightarrow \mathrm{NiAl}_{2} \mathrm{O}_{4}$. In the case of coatings on a Si-Al-O refractory brick (Figure $5 b$ ), all four main nickel aluminide phases are present. On the other hand, coatings on $\mathrm{MgAl}_{2} \mathrm{O}_{4}$ spinel substrate (Figure 4) show only $\mathrm{NiAl}$ and $\mathrm{Ni}_{2} \mathrm{Al}_{3}$ phases.
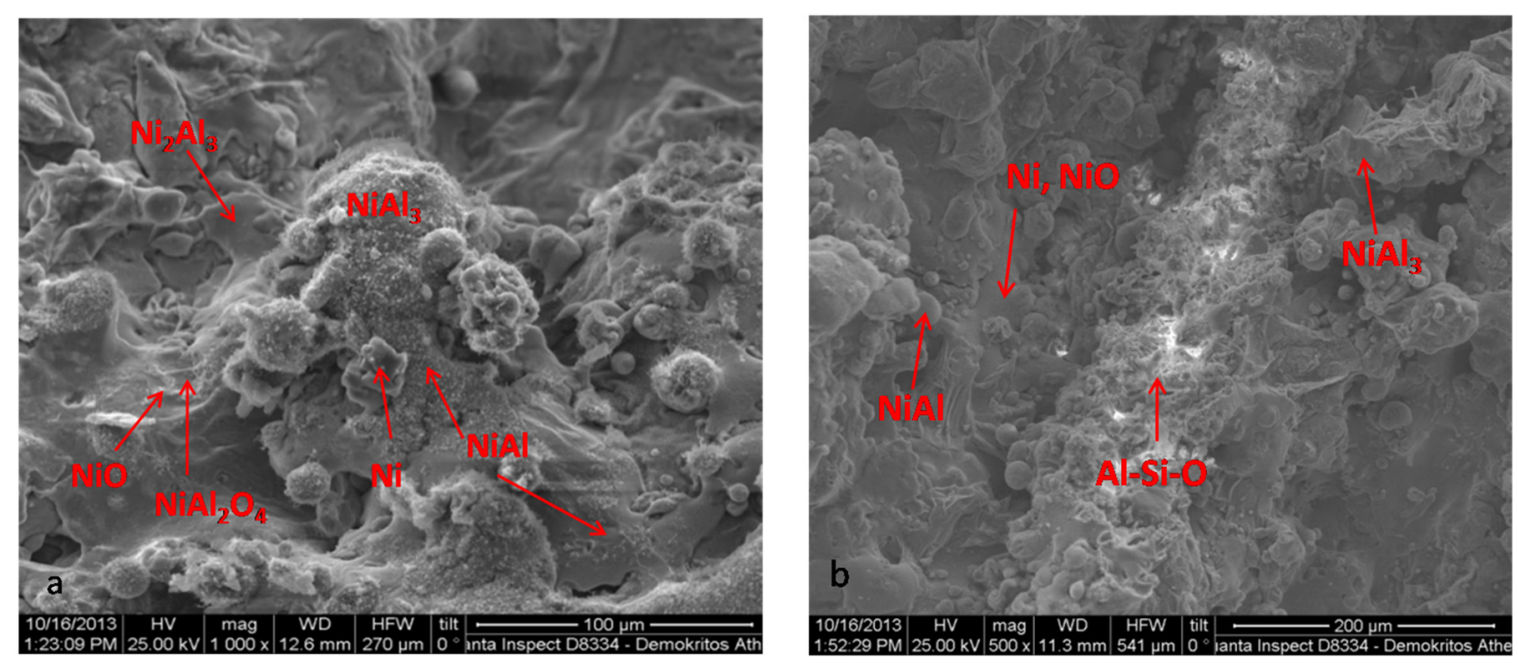

Figure 5. SEM/EDX analysis of catalytic coatings prepared by CAFSY method from initial powder mixture of $65.1 \% \mathrm{Ni}+34.9 \% \mathrm{Al}$ (giving $4 \%$ nickel aluminides in the coating) using one gun pass on (a) spinel (Sp-Ni65-1) and (b) refractory brick (RB-Ni65-1) substrates.

The surface of the coating RB-Ni-65-1 (Figure 6a) shows the presence of the intermetallic phases $\mathrm{NiAl}$ and $\mathrm{Ni}_{3} \mathrm{Al}$ and some traces of $\mathrm{NiO}$. In addition, there are unreacted phases $\mathrm{Ni}$ and $\mathrm{Al}$. Cross-section of the same coating (Figure $6 \mathrm{~b}$ ) shows the formation of intermetallic phases $\mathrm{NiAl}$, $\mathrm{Ni}_{3} \mathrm{Al}$, and $\mathrm{NiAl}_{3}$ and also some traces of NiO. Combining SEM/EDX analysis with the XRD results of the coatings indicates that the light-grey areas in the SEM micrographs are probably $\mathrm{Ni}$-rich, the dark-grey areas are probably Al-rich, while the intermediate-grey areas are probably the intermetallic phases $\mathrm{NiAl}_{3}, \mathrm{NiAl}$, and $\mathrm{Ni}_{3} \mathrm{Al}$. The grey-white areas are probably oxides $\mathrm{Al}_{2} \mathrm{O}_{3}$ and $\mathrm{NiO}$. The $\mathrm{NiAl}_{2} \mathrm{O}_{4}$ spinel phase indicated by XRD could not be found on any surface examined by SEM/EDX.

During CAFSY, the yield of nickel aluminides increases with increasing Ni concentration in the powder mixture. This is because increasing the amount of nickel in the powder mixture increases the temperature of the flame due to the exothermic combustion reaction between nickel and aluminium. This increases the reactivity of the powders in the flame, which increases the net yield of alloys.

The total porosity of the coatings also increases with increasing amount of nickel, because particles melt completely in the flame and tend to splash on the target surface. It is well known that fully molten particles often splash and scatter backwards instead of adhering to the surface, creating a rough surface with increased porosity (e.g., [32]). This also explains the fact that at higher concentration of nickel in the mixture, all of the aluminium has reacted with $\mathrm{NiAl} . \mathrm{Ni}_{3} \mathrm{Al}$ and $\mathrm{NiAl}_{3}$ have low adiabatic temperatures and need high preheating temperatures of substrate [2] to react well. Melted aluminium reacts with $\mathrm{NiAl}$ on the substrate surface, with the subsequent appearance of $\mathrm{NiAl}_{3}$ (Figure $6 \mathrm{~b}$ ). Increasing the substrate temperature increases $\mathrm{NiAl}_{3}$ and $\mathrm{Ni}_{3} \mathrm{Al}$ phases and decreases porosity [2]. 

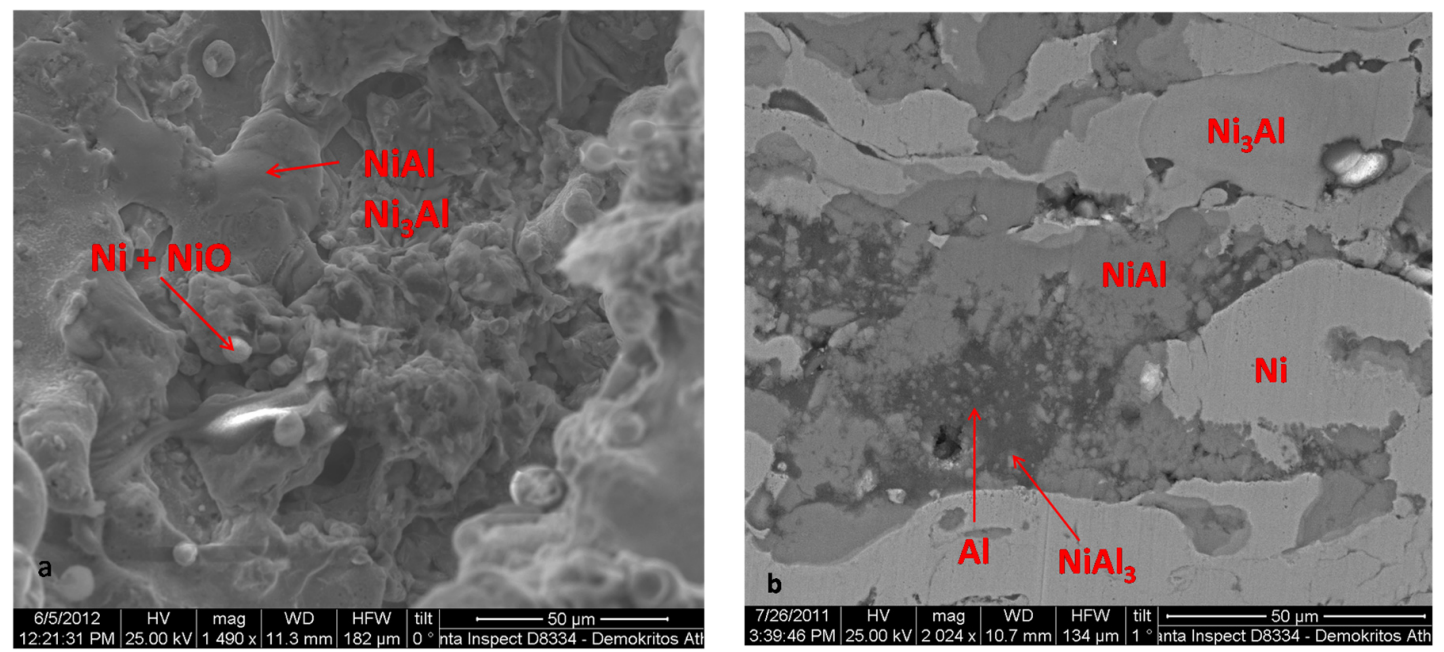

Figure 6. SEM/EDX analysis of the specimen RB-Ni65-1 of (a) surface of the catalytic coating and (b) a cross-section of the coating.

\subsection{Catalytic Activity for Dry Reforming of Methane}

Influence of Substrate Composition

As mentioned, three different substrates were used for thermal spraying of the nickel and aluminium mixtures by CAFSY. All the specimens listed in Table 1 were examined for catalytic activity at $900{ }^{\circ} \mathrm{C}$ for dry reforming of methane. The results of the most promising combinations are shown in Figure 7 compared with the catalytic activity of the three substrates alone.

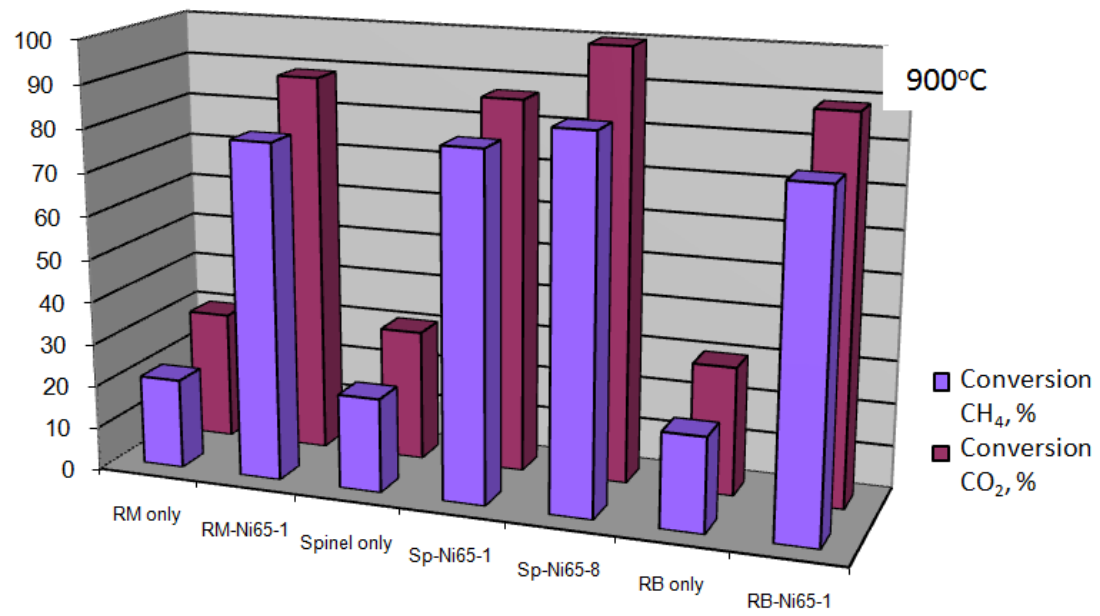

Figure 7. The catalytic activity of the most promising coatings produced by CAFSY for the process of dry reforming with regard to methane and carbon dioxide conversion.

Figure 7 shows that the substrate materials used also display catalytic activity for dry reforming of methane (comparison with data received for substrates without catalytic coatings). The conversion of methane measured on a catalyst containing $4 \mathrm{wt} . \%$ nickel aluminide coating on a standard spinel substrate (Sp-Ni65-1) is higher than that for the same coating on the refractory mats (RM-Ni65-1) and the refractory bricks (RB-Ni-65-1) substrates. On the other hand, carbon dioxide conversion was higher on RM-Ni-65-1 and RB-Ni-65-1 coatings than on the RB-Ni-65-1 coatings, where an increase of total content of nickel aluminides (from 4\% (Sp-Ni65-1) to 70\% (Sp-Ni65-8)) on the substrate leads to an increase of carbon dioxide conversion by $10 \%$. 
More detailed information about the influence of the number of layers (gun passes) on the conversion of methane and carbon dioxide and on the ratio $\mathrm{H}_{2} / \mathrm{CO}$ in the outlet gases is presented in Figure 8.

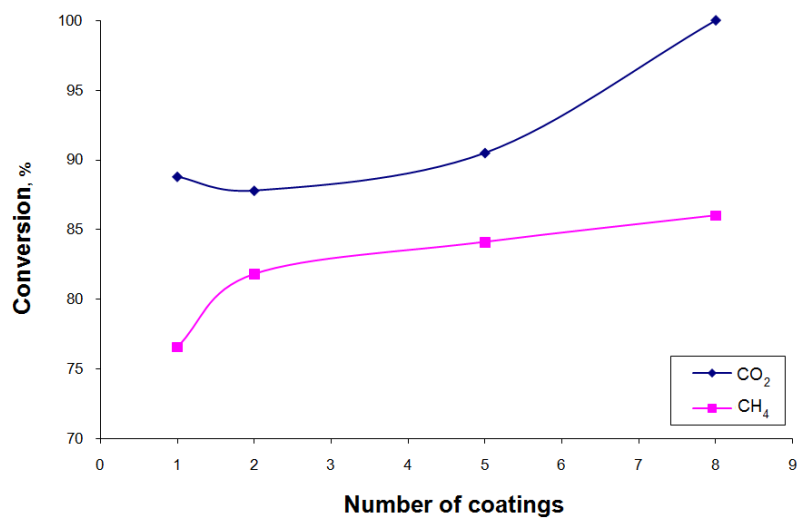

(a)

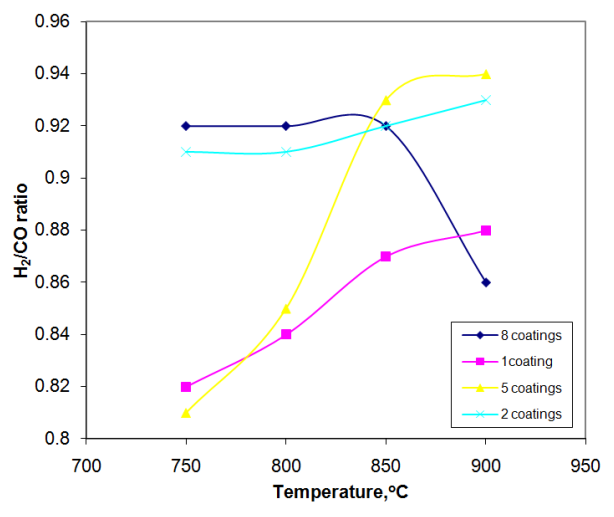

(b)

Figure 8. Influence of (a) number of coatings (gun passes) during CAFSY on the conversion of $\mathrm{CH}_{4}$ and $\mathrm{CO}_{2}$; and (b) temperature of catalysis on the $\mathrm{H}_{2} / \mathrm{CO}$ ratio in the outlet gases.

Figure 8 a shows that increasing the number of catalytic layers from 2 to 8 does not change methane conversion significantly (only by about $3 \%$ ) but does increase $\mathrm{CO}_{2}$ conversion by up to $13 \%$. This means that a catalytic coating with just $4 \%$ nickel aluminide (specimen Sp-Ni65-1) content (this concentration is very often used in industrial catalysis) is very active for carbon dioxide dry reforming of methane.

Ratio of $\mathrm{H}_{2}$ to $\mathrm{CO}$ in the outlet gas produced by the catalytic reaction depends on the number of coatings as well as the reaction temperature. At high temperatures (Figure $8 \mathrm{~b}, 850^{\circ} \mathrm{C}$ ) all catalysts produce gases with a ratio of $0.92-0.94$, which is suitable for industrial synthesis of alcohols, aldehydes, olefins, acetic acid, and so on. At lower temperatures, $750-800{ }^{\circ} \mathrm{C}$, the number of catalytic layers plays a more significant role regarding the efficiency of the catalysts. It is worth noting that at $900{ }^{\circ} \mathrm{C}$, the activity of the $70 \%$ coated catalyst (Sp-Ni65-8) decreases because of coke formation. This could be connected to the increase of contact time on the surface, which increases the concentration of active centres and desorption becomes the limiting factor of catalysis.

The amount of nickel in the initial powder mixture also plays a significant role in the catalyst activity (Figure 9). Significant changes in catalytic activity occur at $42.1 \%-59.3 \% \mathrm{Ni}$ (specimens Sp-Ni42-2 and Sp-Ni59-2), where the main phases in the catalytic coating are: $\mathrm{NiAl}, \mathrm{Ni}_{2} \mathrm{Al}_{3}, \mathrm{Ni}_{3} \mathrm{Al}$.

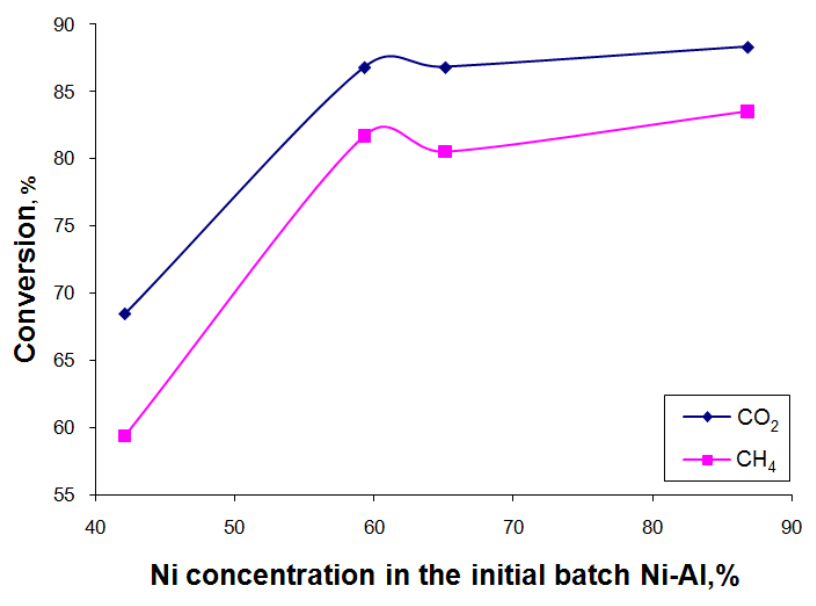

Figure 9. Influence of amount of nickel in the initial mixture on the catalytic activity. 
Reaction temperature, type of substrate, and the amount of nickel aluminides in the coatings affect the $\mathrm{H}_{2} / \mathrm{CO}$ ratio (Figure 10). Such influences could be connected with structural changes during coating.

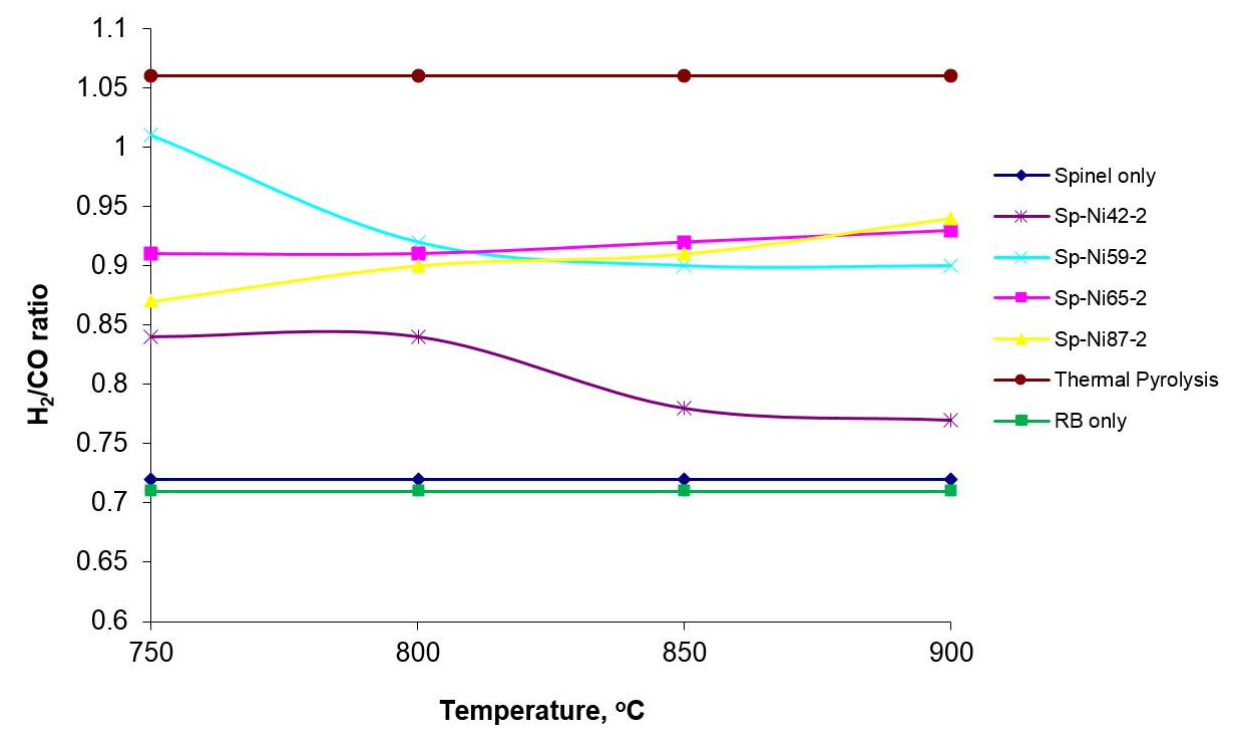

Figure 10. Influence of reaction temperature, type of substrate, and Ni concentration in the initial $\mathrm{Ni}+\mathrm{Al}$ mixture on the $\mathrm{H}_{2} / \mathrm{CO}$ ratio.

\section{Conclusions}

The work presented here demonstrated that the CAFSY coating method is able to rapidly produce low-cost nickel aluminide coatings on substrates with good catalytic properties. Studies of the catalytic activity of such CAFSY nickel aluminide coatings for dry reforming of methane shows that very high conversion rates are possible. By varying the processing parameters, it is possible to obtain a range of materials with varying ratios of the three main catalytic phases $\left(\mathrm{NiAl}, \mathrm{Ni}_{3} \mathrm{Al}\right.$, and $\left.\mathrm{Ni}_{2} \mathrm{Al}_{3}\right)$ on the substrates, with a wide range of catalytic properties. The coating substrates (which serve as carriers for the catalysts) influence the catalytic activity of the nickel aluminide coatings. Such CAFSY coatings can therefore be recommended as a low-cost and convenient method of catalyst production for industrial applications, especially in areas where conversion of flowing gases is required, such as flue outlets.

Acknowledgments: The Authors thank Pyrogenesis S.A. for offering thermal coating equipment for the CAFSY experiments.

Author Contributions: Galina Xanthopoulou conceived and designed the experiments, analysed and discussed the data and co-authored the paper. Amalia Marinou performed the experiments for the thermal coatings, conducted SEM/EDS investigations and analysed and discussed many of the results. Konstantinos Karanasios performed some experiments on catalytic activity of the coatings and finally George Vekinis analysed SEM/EDX and XRD results and co-authored the paper.

Conflicts of Interest: The authors declare no conflict of interest.

\section{References}

1. Marinou, A.; Xanthopoulou, G.; Vekinis, G.; Lekatou, A.; Vardavoulias, M. Synthesis and heat treatment of sprayed high-temperature NiAl-Ni ${ }_{3} \mathrm{Al}$ coatings by in-flight combustion synthesis (CAFSY). Int. J. SHS 2015, 24, 192-201. [CrossRef]

2. Xanthopoulou, G.; Marinou, A.; Vekinis, G.; Lekatou, A.; Vardavoulias, M. NiAl and NiO-Al composite coatings by combustion-assisted flame spraying. Coatings 2014, 4, 231-252. [CrossRef] 
3. Xanthopoulou, G. Self-propagating high-temperature synthesis as method of catalysts production. Sci. Cent. Asia 2010, 4, 35-56.

4. Xanthopoulou, G.; Vekinis, G. Catalytic oxidation of $\mathrm{CO}$ over a Cu-Cr-oxide catalyst made by self-propagating high-temperature synthesis. Appl. Catal. B Environ. 1998, 19, 37-44. [CrossRef]

5. Xanthopoulou, G. Oxide catalysts for pyrolysis of diesel fuel made by self-propagating high-temperature synthesis. Part I: Cobalt-modified Mg-Al spinel catalysts. Appl. Catal. A Gen. 1999, 182, 285-295. [CrossRef]

6. Xanthopoulou, G. Oxide catalysts for pyrolysis of diesel fuel made by self-propagating high-temperature synthesis(SHS): Part II: Fe-Cr oxide catalysts based on chromite concentrates. Appl. Catal. A Gen. 1999, 187, 79-88. [CrossRef]

7. Xanthopoulou, G. Oxidative dehydrodimerization of methane using lead and samarium based catalysts made by self-propagating high-temperature synthesis. Appl. Catal. A Gen. 1999, 185, L185-L192. [CrossRef]

8. Xanthopoulou, G.; Vekinis, G. Deep oxidation of methane using catalysts and carriers produced by self-propagating high temperature synthesis. Appl. Catal. A Gen. 2000, 199, 227-238. [CrossRef]

9. Xanthopoulou, G.; Vekinis, G. An overview of some environmental applications of the self-propagating high-temperature synthesis. Adv. Environ. Res. 2001, 5, 117-128. [CrossRef]

10. Xanthopoulou, G.; Vekinis, G. Catalytic pyrolysis of naphtha on the SHS catalysts. Eurasian Chem. Technol. J. 2010, 12, 17-21. [CrossRef]

11. Dinka, P.; Mukasyan, A.S. Solution combustion catalysts for steam reforming of JP-8 surrogate. J. Power Sources 2007, 167, 472-481. [CrossRef]

12. Hirano, T.; Purwanto, H.; Akiyama, T.W.T. Self-propagating high-temperature synthesis with post-heat treatment of $\mathrm{La}_{1-x} \mathrm{Sr}_{x} \mathrm{FeO}_{3}(x=0-1)$ perovskite as catalyst for soot combustion. J. Alloy. Compd. 2009, 470, 245-249. [CrossRef]

13. Xanthopoulou, G. Catalytic properties of the SHS products-Review. Adv. Sci. Technol. 2010, 63, $287-296$. [CrossRef]

14. Karanasios, K.; Xanthopoulou, G.; Vekinis, G.; Zoumpoulakis, L. Co-Al oxide SHS catalysts for dry reforming of methane. Int. J. Self-Propag. High-Temp. Synth. 2014, 23, 222-231. [CrossRef]

15. Kim, W.Y.; Lee, Y.H.; Park, H.; Choi, Y.H.; Lee, M.H.; Lee, J.S. Coke tolerance of $\mathrm{Ni} / \mathrm{Al}_{2} \mathrm{O}_{3}$ nanosheet catalyst for dry reforming of methane. Catal. Sci. Technol. 2016, 6, 2060-2064. [CrossRef]

16. $\mathrm{Xu}, \mathrm{S}$.; Wang, $\mathrm{X}$. Highly active and coking resistant $\mathrm{Ni} / \mathrm{CeO}_{2}-\mathrm{ZrO}_{2}$ catalyst for partial oxidation of methane. J. Fuel 2005, 84, 563-567. [CrossRef]

17. Pengpanich, S.; Meeyoo, V.; Riksomboon, T. Methane partial oxidation over $\mathrm{Ni} / \mathrm{CeO}_{2}-\mathrm{ZrO}_{2}$ mixed oxide solid solution catalysts. J. Catal. Today 2004, 93-95, 95-105. [CrossRef]

18. Larimi, S.; Alavi, S.M. Partial oxidation of methane over $\mathrm{Ni} / \mathrm{CeZrO}_{2}$ mixed oxide solid solution catalysts. Int. J. Chem. Eng. Appl. 2012, 3, 6-9.

19. Soloviev, S.O.; Kapran, A.Y.; Orlyk, S.N.; Gubareni, E.V. Carbon dioxide reforming of methane on monolithic $\mathrm{Ni} / \mathrm{Al}_{2} \mathrm{O}_{3}$-based catalysts. J. Natur. Gas Chem. 2011, 20, 184-190. [CrossRef]

20. Fidalgo, B.; Arenillas, A.; Menindez, J.A. Synergetic effect of a mixture of activated carbon $+\mathrm{Ni} / \mathrm{Al}_{2} \mathrm{O}_{3}$ used as catalysts for the $\mathrm{CO}_{2}$ reforming of $\mathrm{CH}_{4}$. Appl. Catal. Ser. A 2010, 390, 78-83. [CrossRef]

21. Moniri, A.; Alavi, S.M.; Rezaei, M. Syngas production by combined carbon dioxide reforming and partial oxidation of methane over $\mathrm{Ni} / \alpha-\mathrm{Al}_{2} \mathrm{O}_{3}$ catalysts. J. Nat. Gas Chem. 2010, 19, 638-641. [CrossRef]

22. ALuna, E.C.; Iriarte, M.E. Carbon dioxide reforming of methane over a metal modified $\mathrm{Ni}-\mathrm{Al}_{2} \mathrm{O}_{3}$ catalyst. Appl. Catal. Ser. A 2008, 343, 10-15.

23. Meshkani, F.; Rezaei, M. Nanocrystalline MgO supported nickel-based bimetallic catalysts for carbon dioxide reforming of methane. Int. J. Hydrog. Energy 2010, 35, 10295-10301. [CrossRef]

24. Xanthopoulou, G.; Varitis, S.; Karanasios, K.; Vekinis, G. SHS-Produced Ni-Co-Al-Mg-O catalysts for dry reforming of methane. SHS J. 2014, 23, 92-100. [CrossRef]

25. Sikka, S.K.; Nair, G.J.; Roy, F.; Kakodkar, A.; Chidambaram, R. The recent Indian nuclear tests: A seismic overview. Curr. Sci. 2000, 79, 1359-1366.

26. Itin, V.I.; Naiborodenko, Y.S. High Temperature Synthesis of Intermetallic Compounds; Tomsk University Publisher: Tomsk, Russia, 1989.

27. Morsi, K. Review: Reaction synthesis processing of Ni-Al intermetallic materials. Mater. Sci. Eng. A 2001, 299, 1-15. [CrossRef] 
28. Pidria, M.; Merlone, E.; Rostagno, M.; Tabone, L.; Bechis, F.; Vallauri, D.; Deorsola, F.A.; Amato, I.; Rodriguez, M.A. SHS production, processing and evaluation of advanced materials for wear-resistant cutting tools. Mater. Sci. Forum 2003, 426, 4373-4378. [CrossRef]

29. Xanthopoulou, G.; Marinou, A.; Karanasios, K.; Vekinis, G. Catalytic Activity of NiAl Composite Coatings Produced by In-Flight SHS during Thermal Spraying. In Proceedings of the SHS 2013 International Symposium, South Padre Island, TX, USA, 21-24 October 2013; pp. 277-279.

30. Marinou, A. Synthesis of High Temperature Coatings by the New Method CAFSY. Ph.D. Thesis, University of Ioannina, Ioannina, Greece, 2015.

31. Naiborodenko, Y.S.; Itin, V.I.; Savitskii, K.V. Exothermic effects during sintering of a mixture of nickel and aluminum powders. J. Sov. Phys. 1968, 11, 89-93. [CrossRef]

32. Handbook of Thermal Spray Technology; ASM Thermal Spray Technology; ASM International: Materials Park, OH, USA, 2004.

(C) 2017 by the authors; licensee MDPI, Basel, Switzerland. This article is an open access article distributed under the terms and conditions of the Creative Commons Attribution (CC BY) license (http:/ / creativecommons.org/licenses/by/4.0/). 